
\title{
$\begin{array}{ll}\text { Research Square } & \begin{array}{l}\text { Preprints are preliminary reports that have not undergone peer review. } \\ \text { They should not be considered conclusive, used to inform clinical practice, } \\ \text { or referenced by the media as validated information. }\end{array}\end{array}$
}

\section{Persistence of conjunctival colonization by coagulase-negative staphylococci in patients undergoing cataract surgery}

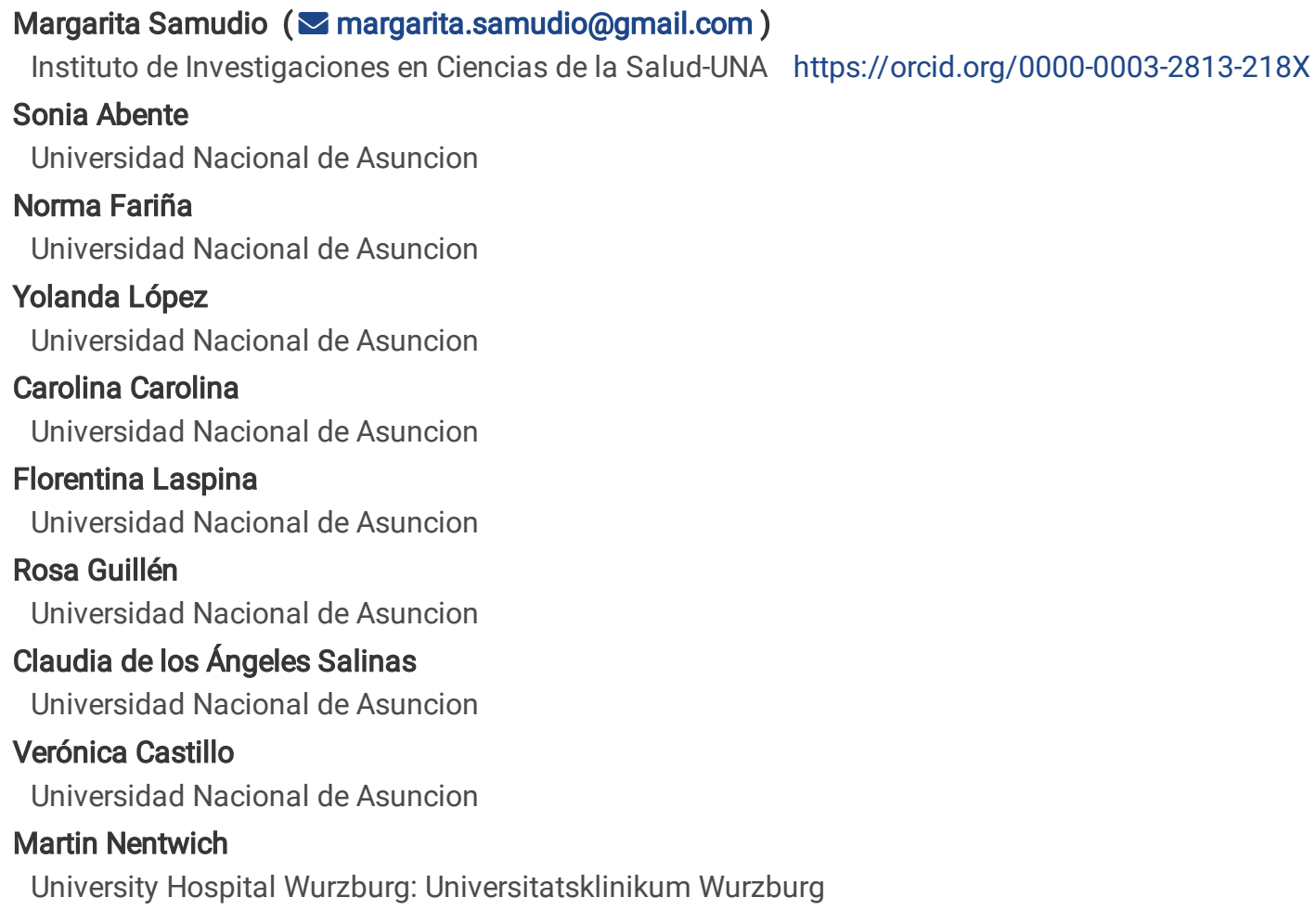

\section{Research Article}

Keywords: Microbiota, S, epidermidis, Cataract surgery, Virulence factors

Posted Date: March 7th, 2022

DOI: https://doi.org/10.21203/rs.3.rs-1311914/v1

License: (c) (i) This work is licensed under a Creative Commons Attribution 4.0 International License. Read Full License 


\section{Abstract}

Purpose

To establish the conjunctival contamination source by coagulase-negative staphylococci (CNS) during cataract surgery and discuss the implications of this colonization as a potential risk of acquiring endophthalmitis.

\section{Methods}

Conjunctiva samples for culture from 59 patients undergoing cataract surgery were taken of the fellow eye at baseline ( $\mathrm{T} 1$ ) and from the eye to be operated before (T0) and immediately after (T2) irrigation with povine-iodine IOP5\%, and at the end of surgery (T3). Genes responsible for virulence $(m e c A$, ica and at $/ E)$ and antibiotic profile were determined; strain clonality of persistent colonizing $S$. epidermidis strains was established by the Multi-locus sequence typing (MLST).

\section{Results}

The frequency of CNS was significantly reduced in T2 (13.6\%) from $81.4 \%$ in T0 and $86.4 \%$ in T1. The frequency of mecA, ica and atIE genes was $35.9 \%, 41.7 \%$ and $67.2 \%$, respectively; and methicillin phenotypic resistance was $35.4 \%$. S. epidermidis was the most frequent species isolated in every time point. MLST revealed in 7 patients $100 \%$ coincidence of the 7 alleles of the $S$. epidermidis isolated previous to povine-iodine $5 \%$ disinfection and at the end of the surgery. CNS isolates from T2 or T3 corresponded to the same species, antibiotic and virulence profile as those isolates from T1 or T0.

\section{Conclusion}

Pre-surgical prophylactic scheme significantly reduced conjunctival contamination; in those that persisted, the source of contamination was mostly the patient's microbiota confirmed by the MLST system.

\section{Introduction}

Although acute postoperative endophthalmitis associated with cataract surgery is rare, it is associated with a high frequency of irreversible vision loss; even with proper treatment [1]. Various prophylactic measures have been adopted in order to reduce the incidence of this devastating complication. It is presumed that the source of infection is the patient's own conjunctival and palpebral microbiota [2]. Prophylactic measures are aimed at eliminating contamination from various sources of infection, especially the conjunctiva and eyelids of the patient [3].

Gram-positive cocci are the most frequently isolated microorganisms in acute postoperative endophthalmitis, such as Staphylococcus epidermidis, Staphylococcus aureus, Streptococcus sp [4]. It has been shown that conjunctival microbiota contaminates the anterior chamber during cataract surgery between $13 \%$ and $42 \%$ with a predominance of gram-positive cocci (S. epidermidis and S. aureus) [5-7].

Disinfection with povidone iodine (PVI) is so far the only measure considered capable of reducing the incidence of endophthalmitis [810]. Our group has shown in previous studies a high contamination rate of the conjunctiva before and after irrigation with $5 \% \mathrm{PVI}$ and at the end of the surgery [11, 12]; as well as the aqueous humor [7]. In addition, a high frequency of virulence factors in strains isolated from the conjunctiva in patients undergoing cataract surgery [13], and from the health personnel [14] were reported. In none of these studies, the source of colonization was established. The objective of this study is to identify the source of conjunctival contamination by comparing the virulence profile of coagulase-negative staphylococci that remained colonizing the conjunctiva after irrigation with $5 \% \mathrm{PVI}$ in patients undergoing cataract surgery by both phenotypic and genotypic methods and discuss the implications of this colonization as a potential risk of acquiring endophthalmitis during cataract surgery.

\section{Methods}

After approval by the Institutional Review Board (IRB) had been obtained, patients presenting for cataract surgery were recruited for this study from October 2016 to May 2017 at the Department of Ophthalmology, Medical School of the National University of Asunción, Paraguay. Cataract surgery is routinely performed at this institution using clear-cornea incision phacoemulsification technique. Those patients with decompensation or pathological clinical condition prior to surgery were excluded. 


\section{Conjunctival samples and patient data}

The ophthalmologist responsible for the surgery was in charge of collecting the samples and completing the patient's data sheet. Four conjunctival samples were collected from upper/lower fornix of each patient using individual sterile cotton swabs moistened with thioglycolate broth; one sample at each of the following times: T0: sample taken from the eye to be operated before irrigation with $5 \%$ povidone iodine solution ( $5 \% \mathrm{PVI}), \mathrm{T} 1$ : from the fellow eye, T2: from the eye to be operated after $5 \% \mathrm{PVI}$ disinfection and T3: of the operated eye at the end of the surgery.

The patient data sheet included general characteristics (sex, age, medical history, side of the operated eye, duration of surgery). In addition, contamination by Coagulase-negative Staphylococci (CNS) species, antibiotic resistance / susceptibility profile, the presence of mecA, ica y at/E genes and MLTS profile were registered.

\section{Microbiological study}

Each sample was inoculated directly into blood agar / chocolate agar. Subsequently, the swab was placed in a tube of thioglycolate broth. The primary plates of blood agar / chocolate agar were incubated at $35^{\circ} \mathrm{C}$ in an atmosphere of $5 \% \mathrm{CO} 2$ for $72 \mathrm{~h}$ and every $24 \mathrm{~h}$ were observed in order to detect bacterial development, and in positive case the colony count was performed. The thioglycolate broth was incubated at $35^{\circ} \mathrm{C}$ for 5 days observing every $24 \mathrm{~h}$ the bacterial development by degree of turbidity and recorded in crosses:,+++ and +++ according to the presence of light, moderate or intense turbidity. Bacteria were identified and tested for antibiotic susceptibility by the Kirby Bauer method against the following drugs: Cefoxitin 30 ug, Erythromycin 15 ug, Clindamycin 2 ug, Penicillin 6 ug, Chloramphenicol 30 ug, Trimethoprim / Sulfamethoxazole 1.25 / 23.75 ug, Ciprofloxacin 5 ug, Gentamicin 10 ug, Tobramycin 10 ug, Moxifloxacin 5 ug, Tetracycline 30 ug, Novobiocin 5 ug, Polymyxin B 100 IU (Biorad, USA) in accordance with Clinical Laboratory Standards Institute guidelines [15].

\section{DNA extraction}

DNA extraction was performed according to a modified lysis method described by Zhang et al. 2004 [16], one to five bacterial colonies obtained from 24-48 hours culture in blood agar were suspended in $200 \mu \mathrm{l}$ sterile distilled water and heated at $100^{\circ} \mathrm{C}$ for $15 \mathrm{~min}$, freezed for $5 \mathrm{~min}$, and then centrifuged at $13.000 \mathrm{rpm}$ for $1 \mathrm{~min}$, supernatant was stored at $-20^{\circ} \mathrm{C}$ until use.

\section{Amplification by Multiplex PCR}

Multiplex PCR for identifying genes: mecA, ica, and at/E was performed according to the method described by Sharma et al. 19[26]. Some changes were introduced to the original protocol. $25 \mathrm{uL}$ master mix $1.5 \mathrm{mM} \mathrm{MgCl}_{2}, 0.4 \mathrm{mM}$ de dNTPs, $1 \mathrm{mM}$ of each primer, $5 \mathrm{U} / \mathrm{ul}$ Taq polimerase and $5 \mu$ of the extracted DNA was added as template.

The oligonucleotide primers used in this study were described by Sharma et al. [17]. The sequence of forward and reverse primers (Bangalore Genei, Bengaluru, Karnataka, India) were as follows: gen ica: Forward ica-TTATCAATGCCGCAGTTGTC e Inverse icaGTTTAACGCGAGTGCGCTAT, (product size: 546 pb); gen mecA: mecA1- GTAGAAATGACTGAACGTCCGATAA and mecA2CCAATTCCACATTGTTTCGGTCTAA, (product size: $310 \mathrm{pb}$ ), and gen AtIE: Forward atIE-CAACTGCTCAACCGAGAACA and inverse AtIETTTGTAGATGTTGTGCCCCA, (product size: 682 pb).

Staphylococcus aureus ATTCC 43300 was used as positive control for mecA gen. A strong biofilm S. epidermidis producer isolated from a patient was used as positive control for atIE, ica genes and double distilled water as negative control.

PCR was performed in a thermocycler PTC-100 (MJ Research. MA, USA) under the following conditions: 30 cycles of denaturation at $94^{\circ} \mathrm{C}$ for $1 \mathrm{~min}$, followed by annealing at $55^{\circ} \mathrm{C}$ for $1 \mathrm{~min}$, and extension at $72^{\circ} \mathrm{C}$ for $2 \mathrm{~min}$. PCR products and $100 \mathrm{pb}$ molecular marker (BIORON) were run at 100 volts for 1 hour in $1.5 \%$ agarose gel and TAE $1 \mathrm{X}$ buffer (Tris-Acetate-EDTA) and visualized by staining with $5 \%$ SYBR® Safe DNA gel stain (Invitrogen, USA).

\section{Clonality}


The single enhanced MLST scheme described by Thomas et al. [18] was used, which develops an MLST scheme consisting of the seven most discriminatory alleles of three schemes. The PCR involved an initial denaturation of $95^{\circ} \mathrm{C}$ for 3 minutes; 34 cycles of $95^{\circ} \mathrm{C}$ for 30 $\mathrm{s}, 50^{\circ} \mathrm{C}$ for 1 minute and $72^{\circ} \mathrm{C}$ for 1 minute; and a final extension of $72^{\circ} \mathrm{C}$ for $10 \mathrm{~min}$. The amplicons were further purified and sequenced. The alleles at each locus were distinguished by using Sequence Output software (available from http://www.mlst.net). Lineages were analyzed by using the eBURST algorithm [19] available at http://eBURST.mlst.net.

Modified primer sequences for an improved S. epidermidis MLST scheme

\begin{tabular}{|lll|}
\hline Gen & Primer & Sequence $5^{\prime} \rightarrow 3^{\prime}$ \\
\hline gtr & gtr-F & CAGCCAATTCTTTTATGACTTTT GTGATTAAAGGTATTGATTTGAAT \\
gtr-R & $\begin{array}{l}\text { mustS-F3 } \\
\text { mutS-R3 }\end{array}$ & GATATAAGAATAAGGGTTGTGAA GTAATCGTCTCAGTTATCATGTT \\
\hline tpi & $\begin{array}{l}\text { tpi-F2 } \\
\text { tpi-R2 }\end{array}$ & ATCCAATTAGACGCTTTAGTAAC TTAATGATGCGCCACCTACA \\
\hline yqiL & $\begin{array}{l}\text { yqiL-F2 } \\
\text { yqiL-R2 }\end{array}$ & CACGCATAGTATTAGCTGAAG CTAATGCCTTCATCTTGAGAAATAA \\
pyr-F2 & GTTACTAATACTTTTGCTGTGTTT GTAGAATGTAAAGAGACTAAAATGAA \\
pyr-R4 & arcC-F & TGTGATGAGCACGCTACCGTTAG TCCAAGTAAACCCATCGGTCTG \\
arcC-R & \\
\hline aroE & $\begin{array}{l}\text { aroE-F } \\
\text { aroE-R }\end{array}$ & CATTGGATTACCTCTTTGTTCAGC CAAGCGAAATCTGTTGGGG \\
\hline
\end{tabular}

The new gene sequences reported in this study have been deposited in the GenBank (access numbers DQ991011 to DQ991028).

The data were analyzed by descriptive statistics, using the Epi info 3.5.1 program (CDC, Atlanta). Results are expressed as an absolute and relative percentage frequency distribution.

\section{Results}

Fifty-nine patients, 37 women and 22 men between 23 and 89 years of age (mean age \pm standard deviation: $66.9 \pm 12.6$ years) were studied. The most frequent pre-existing condition was arterial hypertension. Duration of surgery ranged from 14 to 55 minutes with a mean duration of $26.2 \pm 8.6$ minutes. Table 1 . 
Table 1

Characteristics of patients undergoing cataract surgery. $n=59$

\begin{tabular}{|c|c|c|}
\hline Characteristics & Frecuency & Percentage \\
\hline \multicolumn{3}{|l|}{ Sex } \\
\hline $\mathrm{F}$ & 37 & 62.7 \\
\hline M & 22 & 37.3 \\
\hline Age (average \pm SD, range) & $66.9 \pm 12.6(23-89)$ years & \\
\hline$<40$ & 3 & 5.1 \\
\hline $40-59$ & 12 & 20.3 \\
\hline $60-69$ & 14 & 23.7 \\
\hline$\geq 70$ & 30 & 50.9 \\
\hline \multicolumn{3}{|l|}{ Underlying conditions } \\
\hline Arterial hypertension (AHT) & 23 & 39.0 \\
\hline Diabetes mellitus - AHT & 8 & 13.6 \\
\hline Diabetes mellitus & 4 & 6.8 \\
\hline Other (hypothyroidism, HIV) & 2 & 3.4 \\
\hline \multicolumn{3}{|l|}{ Operated eye } \\
\hline Right /left & $32 / 27$ & $54.2 / 45.8$ \\
\hline \multicolumn{3}{|l|}{ Duration of surgery (minutes) } \\
\hline (Average $\pm \mathrm{SD}$, range) & $26.2 \pm 8.6(14-55)$ & \\
\hline$<20$ & 6 & 10.2 \\
\hline $20-30$ & 42 & 71.1 \\
\hline$>30$ & 11 & 18.7 \\
\hline
\end{tabular}

A significant decrease in ocular microbiota was obtained after disinfection with $5 \%$ povidone-iodine (T2) and an increase in positivity of cultures at the end of surgery (T3). Figure 1

Table 2 shows the results of the microbiological cultures of the samples taken at the three time points, T0: before surgery of the eye to be operated; T1: from the unoperated eye as a control, T2: immediately after receiving standard disinfection with $5 \%$ povidone-iodine. T3: at the end of the surgery. The frequency of positive culture for CNS was $42.4 \%$ in the initial plate in T1 and in the broth $62.7 \%$. At T0 it was $35.6 \%$ in the plaque and $61.0 \%$ in broth; in T2 it was $6.8 \%$ and $16.9 \%$, respectively. In T3 it was $6.8 \%$ and $28.8 \%$ and $33.9 \%$, respectively. The number of colonies recovered in the cultures was generally low; approximately $50 \%$ with less than 5 colonies before disinfection; in T2 less than 5 colonies were obtained in all positive cases and in T3 less than 20 colonies in all positive cases. Also, the degree of turbidity in the thioglycolate broths at different time points is shown. 
Table 2

Primary Plate Colony Count and Broth Turbidity

\begin{tabular}{|c|c|c|c|c|}
\hline & T1 & TO & T2 & T3 \\
\hline & $\mathrm{n}=25(42.7)$ & $\mathrm{n}=21(35.6)$ & $\mathrm{n}=4(6.8)$ & $\mathrm{n}=4(6.8)$ \\
\hline \multicolumn{5}{|l|}{ Colony counts in primary plaques } \\
\hline$<5$ & 7 & 14 & 4 & 1 \\
\hline 5 a 20 & 6 & 2 & - & 3 \\
\hline$>20$ & 12 & 5 & - & - \\
\hline Turbidity in thioglycolate broth & $\mathrm{n}=37(62.7)$ & $\mathrm{n}=36(61.0)$ & $\mathrm{n}=10(16.9)$ & $n=17(28.8)$ \\
\hline $1+$ & 20 & 19 & 6 & 8 \\
\hline $2+$ & 12 & 12 & 2 & 6 \\
\hline $3+$ & 5 & 2 & - & 1 \\
\hline Traces & - & 3 & 2 & 2 \\
\hline \multicolumn{5}{|c|}{ T0: before surgery from the eye to be operated } \\
\hline \multicolumn{5}{|l|}{ T1: from the fellow eye as control } \\
\hline \multicolumn{5}{|c|}{ T2: immediately after standard 5\%PVI disinfection } \\
\hline T3: at the end of the surgery & & & & \\
\hline
\end{tabular}

From the 59 patients, 192 CNS isolates were obtained; 75 at T0; 76 in T1; 14 in T2 and 27 in T3. Table 3 shows the frequency of the different CNS species obtained, $S$. epidermidis was the most frequent species, followed by $S$. hominis.

Table 3

Negative coagulase staphylococci isolates

\begin{tabular}{|lll|}
\hline Bacteria species & Frequency & Percentage \\
\hline S. epidermidis & 116 & 60.4 \\
\hline S. hominis subesp hominis & 27 & 14.1 \\
\hline S. Iugdunensis & 12 & 6.3 \\
\hline S. capitis subesp capitis & 11 & 5.7 \\
\hline S. haemolyticus & 7 & 3.6 \\
\hline S. schleiferi subesp schleiferi & 5 & 2.6 \\
\hline S. caprae & 8 & 4.2 \\
\hline S. simulans & 3 & 1.6 \\
\hline S. warneri & 2 & 1.0 \\
\hline S. caprae/simulans & 1 & 1.0 \\
\hline Total & 192 & 100.0 \\
\hline
\end{tabular}

Table 4 presents the resistance profile of the CNS isolates. Methicillin resistance was $35.4 \%$. 
Table 4

Antibiotic-resistance profile in CNS strains from ocular microbiota. $n=192$

\begin{tabular}{|llll|}
\hline ATB & Resistant & Intermediate & Sensible \\
\hline FOX & $68(35.4 \%)$ & - & $124(64.6 \%)$ \\
\hline ERY & $48(25.0 \%)$ & $6(3.1 \%)$ & $138(71.9 \%)$ \\
\hline CLI & $16(8.3 \%)$ & $2(1.0 \%)$ & $174(90.6 \%)$ \\
\hline CLO & $37(19.3 \%)$ & $2(1.0 \%)$ & $153(79.7 \%)$ \\
\hline MOX & $13(6.8 \%)$ & $16(8.3 \%)$ & $163(84.9 \%)$ \\
\hline CIP & $39(20.3 \%)$ & $9(4.7 \%)$ & $144(75.0 \%)$ \\
\hline PEN & $133(69.3)$ & - & $59(30.7 \%)$ \\
\hline TMS & $21(10.9 \%)$ & $1(0.5 \%)$ & $170(88.5 \%)$ \\
\hline TET & $23(12.0 \%)$ & $11(5.7 \%)$ & $150(78.1 \%)$ \\
\hline GEN & $31(16.1 \%)$ & $8(4.2 \%)$ & $165(85.9 \%)$ \\
\hline TOB & $19(9.9 \%)$ & - & \\
\hline FOX Cefoxitin, ERI Erythromycin, CLI Clindamycin, PEN Penicillin, CLO Chloramphenicol, TMS Trimethoprim / Sulfamethoxazole, CIP \\
\hline Ciprofloxacin, GEN Gentamycin, TOB Tobramycin, MOX Moxifloxacin, TET Tetracycline
\end{tabular}

The results of gene amplification by multiplex PCR are shown in Table 5. At the different time points, the atlE gene was the most frequently found (61.4\%).

Table 5

Frequency of genes encoding virulence factors in CNS isolates in ocular microbiota. $n=192$

\begin{tabular}{|lcclll|}
\hline Virulence factor gene & T0 (n=75) & T1 (n= 76) & T2 (n=14) & T3 (n=27) & Total (n=192) \\
\hline mecA & $31(41.3 \%)$ & $28(36.9 \%)$ & $5(35.7 \%)$ & $2(7.4 \%)$ & $66(34.4 \%)$ \\
\hline ica & $29(38.7 \%)$ & $32(42.1 \%)$ & $4(28.6 \%)$ & $7(25.9 \%)$ & $72(37.5 \%)$ \\
\hline at/E & $46(61.3 \%)$ & $55(72.4 \%)$ & $6(42.8 \%)$ & $11(40.7 \%)$ & $118(61.4 \%)$ \\
\hline none & $21(28 \%)$ & $18(23.7 \%)$ & $2(14.3 \%)$ & $8(29.6 \%)$ & $49(25.5 \%)$ \\
\hline T0: before surgery from the eye to be operated & & & \\
\hline T1: from the fellow eye as control & & & & \\
\hline T2: immediately after standard 5\%PVI disinfection & & & \\
\hline
\end{tabular}


Table 6

Characteristics of CNS strains recovered after disinfection with $5 \% \mathrm{PVI}$ and at the end of surgery in patients undergoing cataract surgery

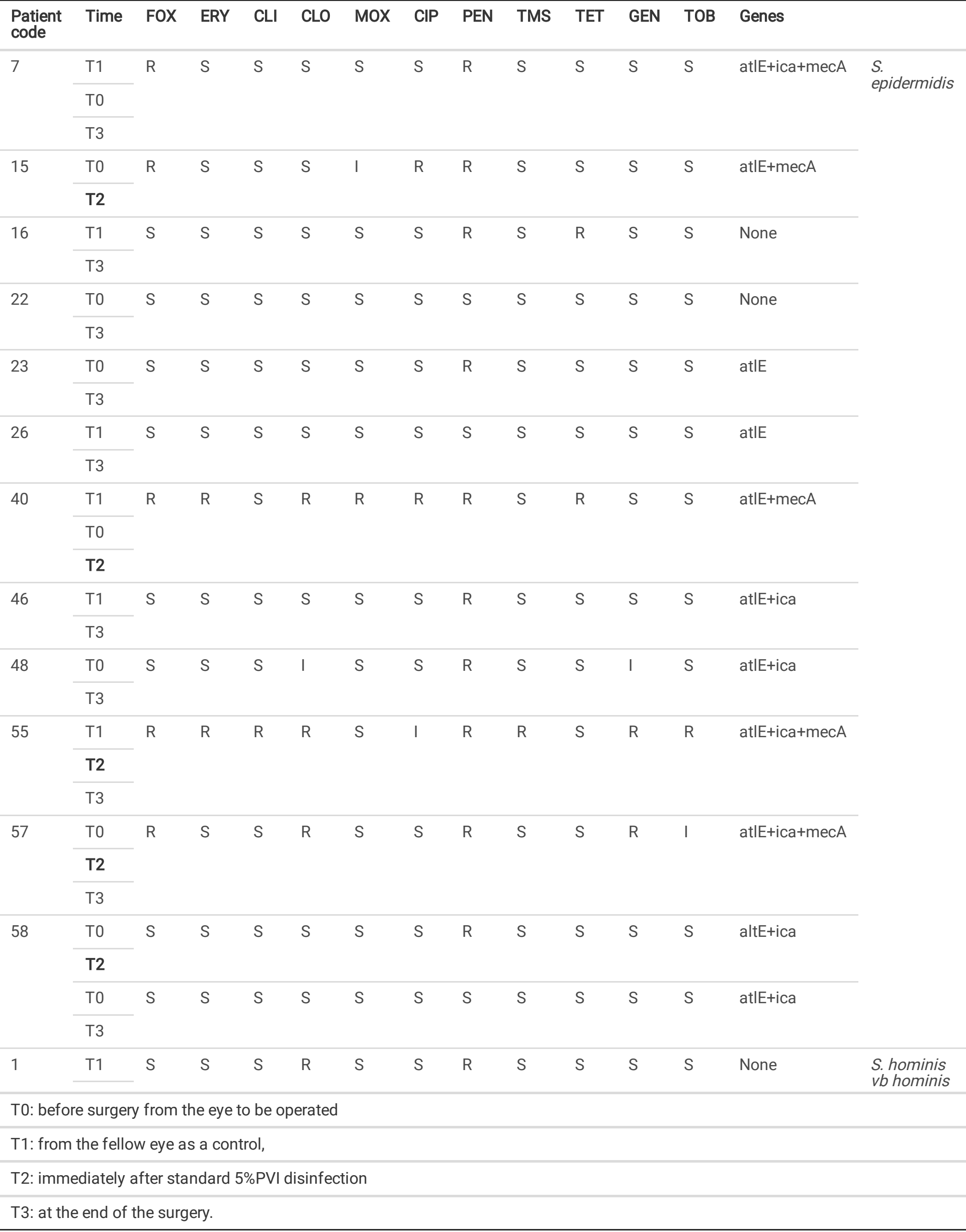




\begin{tabular}{|c|c|c|c|c|c|c|c|c|c|c|c|c|c|c|}
\hline $\begin{array}{l}\text { Patient } \\
\text { code }\end{array}$ & Time & FOX & ERY & CLI & CLO & MOX & CIP & PEN & TMS & TET & GEN & TOB & Genes & \\
\hline & $\mathrm{T} 2$ & & & & & & & & & & & & & \\
\hline \multirow[t]{4}{*}{2} & T0 & \multirow[t]{2}{*}{$S$} & \multirow[t]{2}{*}{$S$} & \multirow[t]{2}{*}{ S } & \multirow[t]{2}{*}{$S$} & \multirow[t]{2}{*}{$S$} & \multirow[t]{2}{*}{ S } & \multirow[t]{2}{*}{$\mathrm{R}$} & \multirow[t]{2}{*}{$S$} & \multirow[t]{2}{*}{$S$} & \multirow[t]{2}{*}{$S$} & \multirow[t]{2}{*}{$S$} & \multirow[t]{2}{*}{ atlE+ica } & \multirow{2}{*}{$\begin{array}{l}\text { S. capitis vb } \\
\text { capitis }\end{array}$} \\
\hline & T2 & & & & & & & & & & & & & \\
\hline & TO & \multirow[t]{2}{*}{$S$} & \multirow[t]{2}{*}{$S$} & \multirow[t]{2}{*}{ S } & \multirow[t]{2}{*}{ S } & \multirow[t]{2}{*}{ S } & \multirow[t]{2}{*}{$S$} & \multirow[t]{2}{*}{ S } & \multirow[t]{2}{*}{ S } & \multirow[t]{2}{*}{$S$} & \multirow[t]{2}{*}{$S$} & \multirow[t]{2}{*}{ S } & \multirow[t]{2}{*}{ atlE+ica } & \multirow{2}{*}{$\begin{array}{l}\text { S. schleiferi } \\
v b \text { schleifer }\end{array}$} \\
\hline & T3 & & & & & & & & & & & & & \\
\hline \multirow[t]{2}{*}{14} & TO & \multirow[t]{2}{*}{ S } & \multirow[t]{2}{*}{ S } & \multirow[t]{2}{*}{ S } & \multirow[t]{2}{*}{ S } & S & $S$ & S & S & $S$ & S & $S$ & None & $S$. \\
\hline & T3 & & & & & & & & & & & & & \\
\hline 28 & $\mathrm{~T} 1$ & S & S & S & S & S & $S$ & $\mathrm{R}$ & $S$ & S & S & S & None & \\
\hline & TO & & & & & & & & & & & & & \\
\hline & $\mathrm{T} 2$ & & & & & & & & & & & & & \\
\hline & T3 & & & & & & & & & & & & & \\
\hline 34 & T1 & $S$ & $S$ & S & S & S & $S$ & S & S & S & S & S & None & \\
\hline & T0 & & & & & & & & & & & & & \\
\hline & Т3 & & & & & & & & & & & & & \\
\hline T0: befol & e surge & from & e eye & o be ol & erated & & & & & & & & & \\
\hline $\mathrm{T} 1$ : from & the fellc & w eye a & a con & & & & & & & & & & & \\
\hline T2: imm & ediately & fter sta & ndard & $\% \mathrm{PVI}$ & isinfec & & & & & & & & & \\
\hline T3: at th & and of & he surg & ery. & & & & & & & & & & & \\
\hline
\end{tabular}

In 17 patients (28.8\%), persistence of CNS strains was observed after $5 \%$ povidone-iodine or at the end of the surgery for CNS with the same virulence profile. In 12 patients, the species that remained colonizing the conjunctiva was S. epidermidis. In four of them, the species that was colonizing the eye to be operated was recovered in T2 and the rest was recovered in the operated eye at the end of the surgery. In five patients, the strains were different from S. epidermidis. Table 7 
Table 7

MLST profile of $S$. epidermidis isolated from patient's conjunctiva at three-point times

\begin{tabular}{|c|c|c|c|c|c|c|c|c|c|}
\hline Patient & Strain & gtr & muts & tpi & yqil & pyr & arc & aroe & ST sequence \\
\hline & $7 a$ & 2 & 1 & 1 & 1 & 2 & 1 & 1 & 89 \\
\hline \multirow[t]{2}{*}{7} & $7 b$ & 2 & 1 & 1 & 1 & 2 & 1 & 1 & 89 \\
\hline & $7 c$ & 2 & 1 & 1 & 1 & 2 & 1 & 1 & 89 \\
\hline \multirow[t]{2}{*}{15} & $15 a$ & 2 & 2 & 1 & 1 & 2 & 1 & 1 & 6 \\
\hline & $15 d$ & 2 & 2 & 1 & 1 & 2 & 1 & 1 & 6 \\
\hline \multirow[t]{3}{*}{40} & $40 a$ & 1 & 1 & 1 & 1 & 2 & 2 & 1 & 59 \\
\hline & $40 \mathrm{~b}$ & 1 & 1 & 1 & 1 & 2 & 2 & 1 & 59 \\
\hline & $40 c$ & 1 & 1 & 1 & 1 & 2 & 2 & 1 & 59 \\
\hline \multirow[t]{3}{*}{55} & $55 a$ & 6 & 1 & 1 & 10 & 2 & 1 & 6 & 173 \\
\hline & $55 b$ & 6 & 1 & 1 & 10 & 2 & 1 & 6 & 173 \\
\hline & $55 c$ & 6 & 1 & 1 & 10 & 2 & 1 & 6 & 173 \\
\hline \multirow[t]{3}{*}{57} & $57 a$ & 2 & 1 & 1 & 1 & 2 & 1 & 1 & 89 \\
\hline & $57 b$ & 2 & 1 & 1 & 1 & 2 & 1 & 1 & 89 \\
\hline & $57 c$ & 2 & 1 & 1 & 1 & 2 & 1 & 1 & 89 \\
\hline \multirow[t]{2}{*}{58} & $58 a$ & 6 & 4 & * & 13 & 29 & * & 22 & * \\
\hline & $58 c$ & 2 & 4 & 6 & 9 & 9 & $\star$ & 2 & $\star$ \\
\hline \multirow[t]{2}{*}{46} & $46 a$ & 9 & 5 & 1 & 1 & 2 & 1 & 1 & 284 \\
\hline & $46 b$ & 9 & 5 & 1 & 1 & 2 & 1 & 1 & 284 \\
\hline \multirow[t]{2}{*}{48} & $48 a$ & 2 & 1 & 1 & 3 & 1 & 1 & 2 & 488 \\
\hline & $48 b$ & 2 & 1 & 1 & 3 & 1 & 1 & 2 & 488 \\
\hline
\end{tabular}

S. epidermidis strains that remained colonizing the conjunctiva of 8 patients were analyzed by the MLTS system; in seven patients, $S$. epidermidis isolates corresponded to the same clone. Overall, six different STs were detected, ST89 was found in two patients. In the remaining 5 patients, different ST were identified. The MLST profile of the S. epidermidis strains is shown in Table 7.

\section{Discussion}

In this study, we used the MLST system to explore the relationship between $S$. epidermidis strains recovered previous irrigation with $5 \%$ $\mathrm{PVI}$ and at the end of the surgery in patients undergoing cataract surgery; 7 out of 8 strains of $S$. epidermidis isolated at both time-points had the same ST profile, indicating that they corresponded to the same clone.

Overall, 6 different STs were detected, ST89 was found in two patients. In the remaining 5 patients, different ST were identified. In the case of S. epidermidis ST59 isolates, there are several reports worldwide regarding their ability to carry multiple antibiotic resistance genes and their ability to form biofilm in isolates obtained from both the environment and from health personnel [20, 21]. Likewise, a study focused on the molecular characterization of $S$. epidermidis isolates that cause ocular infections, pointed to clone ST59 as one of the most frequent, as well as to other members of the clonal complex CC2 [22]. The members of this clonal complex are characterized by being strong biofilm formers, in many cases independently of the ica genes, and this characteristic could be responsible for the persistence of these isolates even after the decontamination procedure with povidone iodine.

Information on S. epidermidis isolates of the ST89 sequence is scarce; however, its detection is important because it shows the clonal diversity of $S$. epidermidis isolates, reinforcing the hypothesis that they came from the ocular microbiota of patients and not from the 
hospital. Although the molecular biological technique used is very sensitive, they are not definitive. Definitive proof of the genetic identity of two organisms would require sequencing and comparison of the entire genome, which is not practical.

The pre-surgical prophylactic scheme significantly reduced conjunctival contamination, which coincides with results published by Li et al. [23, 24], and Nentwich et al. [25] who found that IOP prophylaxis is the most effective prophylactic measure and does not carry the risk of selecting resistant strains. Therefore, very potent topical antibiotics should be reserved for infectious ones and not be used as a mere prophylactic measure to reduce the risk of creating new resistance.

The multiplex PCR used in this study could be useful for the detection of virulence and for the differentiation of more virulent strains of CNS. The genes involved in the production of biofilm have been suggested by some authors such as Ishak et al. [26] and Galdbart et al. [27] as clinically significant markers of CNS strains; however, Araujo et al. [28] found a large percentage of methicillin-resistant commensal CNSs carrying the ica and atIE genes. The results of the present study are in agreement with previous work carried out by our group in which a high percentage of the ocular microbiota of patients undergoing cataract surgery carries encoding virulence factor genes [11-13]. In addition, we have shown a significant percentage of patients showed conjunctival isolates before surgery that recovered again after disinfection with $5 \%$ povidone-iodine or at the end of surgery. These strains, apart from being of the same species, showed the same profile of virulence, antibiotype and clonality factors. This highlights the potential danger of the ocular microbiota for post-surgical complications.

\section{References}

1. Ciulla T, Starr MB, Masket S (2002) Bacterial endophthalmitis prophylaxis for cataract surgery: an evidence-based update. Ophthalmology 109:13-26

2. Mamalis N, Kearsley L, Brinton E (2002) Postoperative endophthalmitis. Curr Opin Ophthalmol 13:14-18

3. Speaker MG, Milch FA, Shah MK, Eisner W, Kreiswirth BN (1991) Role of external bacterial biota in the pathogenesis of acute postoperative endophthalmitis. Ophthalmology 98:639-649

4. Callegan M, Engelbert M, Parke D, Bradley D (2002) Bacterial endophthalmitis: epidemiology, therapeutics, and bacterium-host interactions. Clin Microbiol Rev 15:111-124

5. Ariyasu RG, Nakamura T, Trousdale MD, Smith RE (1993) Intraoperative bacterial contamination of the aqueous humor. Ophthalmic Surg 24:367-373

6. Dickey JB, Thompson KD, Jay WM (1991) Anterior chamber aspirate cultures after uncomplicated cataract surgery. Am J Ophthalmol 112:278-282

7. Cibils D, Samudio M, Laspina F, Fariña N, Rosa Sanabria R, De Miño H Contaminación del humor acuoso en pacientes sometidos a cirugía de cataratas. Mem. Inst. Investig. Cienc. Salud. 2006 Dec; 4(2):19-27. Available from: http://scielo.iics.una.py/scielo.php? script=sci_arttext\&pid=S1812-95282006000200005\&lng=en

8. Speaker MG, Menikoff JA (1991) Prophylaxis of endophthalmitis with topical povidone-iodine. Ophthalmology 98:1769-1775

9. Schmitz S, Dick HB, Krummenauer F, Pfeiffer N (1999) Endophthalmitis in cataract surgery. Results of a German survey. Ophthalmology 106:1869-1877

10. Mino de Kaspar H, Ta C, Egbert P, Singh K (2005) Prospective randomized comparison of 2 different methods of $5 \%$ povidone-iodine applications for anterior segment intraocular surgery. Arch Ophthalmol 123:161-165

11. Carron A, Samudio M, Laspina F, Fariña N, Sanabria RR, Cibils D, Ramirez L, Carron J, de Mino H (2013 Sep) [Efficacy of topical $0.3 \%$ ciprofloxacin application in reducing the conjunctival biota of patients undergoing cataract extraction]. Arch Soc Esp Oftalmol 88(9):345-351

12. Quiroga LP, Lansingh V, Laspina F, Samudio M, Stanley J, Kaspar HM, Cibils D, Cibils P (2010 Mar-Apr) A prospective study demonstrating the effect of $5 \%$ povidone-iodine application for anterior segment intraocular surgery in Paraguay. Arq Bras Oftalmol 73(2):125-128

13. López Y, Samudio M, Fariña N, Castillo V, Abente S, Nentwich MM, González-Britez N, Laspina F, Carron A, Cibils D, de Kaspar HM (2017 Aug) Effect of antibiotic prophylaxis on Coagulase-negative Staphylococcus virulence factor profiles in patients undergoing cataract surgery. Int Ophthalmol 37(4):929-937

14. Fariña N, Samudio M, Carpinelli L, Nentwich MM, de Kaspar HM (2017 Aug) Methicillin resistance and biofilm production of Staphylococcus epidermidis isolates from infectious and normal flora conjunctiva. Int Ophthalmol 37(4):819-825 
15. Clinical and Laboratory Standards Institute (CLSI) (2016) Performance Standards for Antimicrobial Susceptibility testing; twenty fourth informational supplement. 34:M100-S211

16. Zhang K, Sparling J, Chow B, Elsayed S, Hussain Z, Church D et al (2004) New quadriplex PCR assay for detection of methicillin and mupirocin resistance and simultaneous discrimination of Staphylococcus aureus from coagulase-negative staphylococci. J Clin Microbiol 42(11):4947-4955

17. Sharma P, Lahiri K, Kapila K (2011) Conventional and molecular characterization of coagulase negative staphylococcus in hospital isolates. Indian J Pathol Microbio 54:85-89

18. Thomas JC, Vargas MR, Miragaia M, Peacock SJ, Archer GL, Enright MC Improved multilocus sequence typing scheme for Staphylococcus epidermidis.J Clin Microbiol. 2007Feb; 45(2):616-9. Epub 2006 Dec 6.

19. Holden MT, Feil EJ, Lindsay JA, Peacock SJ, Day NP, Enright MC et al Complete genomes of two clinical Staphylococcus aureus strains: evidence for the rapid evolution of virulence and drug resistance.Proc Natl Acad Sci U S A. 2004 Jun29;101(26):9786-91. doi: 10.1073/pnas.0402521101

20. Xu Z, Misra R, Jamrozy D, Paterson GK, Cutler RR, Holmes MA, Gharbia S, Mkrtchyan HV (2018) Whole Genome Sequence and Comparative Genomics Analysis of Multi-drug Resistant Environmental Staphylococcus epidermidis ST59. G3 (Bethesda). Jul 2;8(7):2225-2230. doi: 10.1534/g3.118.200314

21. Xu Z, Cave R, Chen L, Yangkyi T, Liu Y, Li K, Meng G, Niu K, Zhang W, Tang N, Shen J, Mkrtchyan H (2020) Antibiotic resistance and molecular characteristics of methicillin-resistant Staphylococcus epidermidis recovered from hospital personnel in China. Journal of Global Antimicrobial Resistance 22:195-201. https://doi.org/10.1016/j.jgar.2020.02.013

22. Bispo PJ, Hofling-Lima AL, Pignatari AC Characterization of ocular methicillin-resistant Staphylococcus epidermidis isolates belonging predominantly to clonal complex 2 subcluster II.J Clin Microbiol. 2014May; 52(5):1412-7. doi: 10.1128/JCM.03098-13

23. Li B, Nentwich MM, Hoffmann LE, Haritoglou C, Kook D, Kampik A, Sheng M, Miño de Kaspar H (2013 Jul) Comparison of the efficacy of povidone-iodine $1.0 \%, 5.0 \%$, and $10.0 \%$ irrigation combined with topical levofloxacin $0.3 \%$ as preoperative prophylaxis in cataract surgery. J Cataract Refract Surg 39(7):994-1001

24. Li B, Miño de Kaspar H, Haritoglou C, Kook D, Kampik A, Sheng M, Nentwich MM (2015 Apr) Comparison of 1-day versus 1-hour application of topical neomycin/polymyxin-B before cataract surgery. J Cataract Refract Surg 41(4):724-731

25. Nentwich MM, Rajab M, Ta CN, He L, Grueterich M, Haritoglou C, Gandorfer A, Kampik A, De Mino H (2012) Application of 10\% povidone iodine reduces conjunctival bacterial contamination rate in patients undergoing cataract surgery. Eur $\mathrm{J}$ Ophthalmol. JulAug;22(4):541-6

26. Ishak M, Gröschel D, Mandell G, Wenzel R (1985) Association of slime with pathogenicity of coagulase-negative staphylococci causing nosocomial septicemia. J Clin Microbiol 22:1025

27. Galdbart J, Allignet J, Tung H, Rydèn C, El Solh N (2000) Screening for Staphylococcus epidermidis markers discriminating between skin-flora strains and those responsible for infections of joint prostheses. J Infect Dis 182:351-355

28. Araujo G, Coelho R, Barbosa de Carvalho C, Maciel M, Zambrana Coronado A, Rozenbaum R et al (2006) Commensal isolates of methicillin-resistant Staphylococcus epidermidis are also well equipped to produce biofilm on polystyrene surfaces. J Antimicrob Chemother 57(5):855-864

\section{Figures}




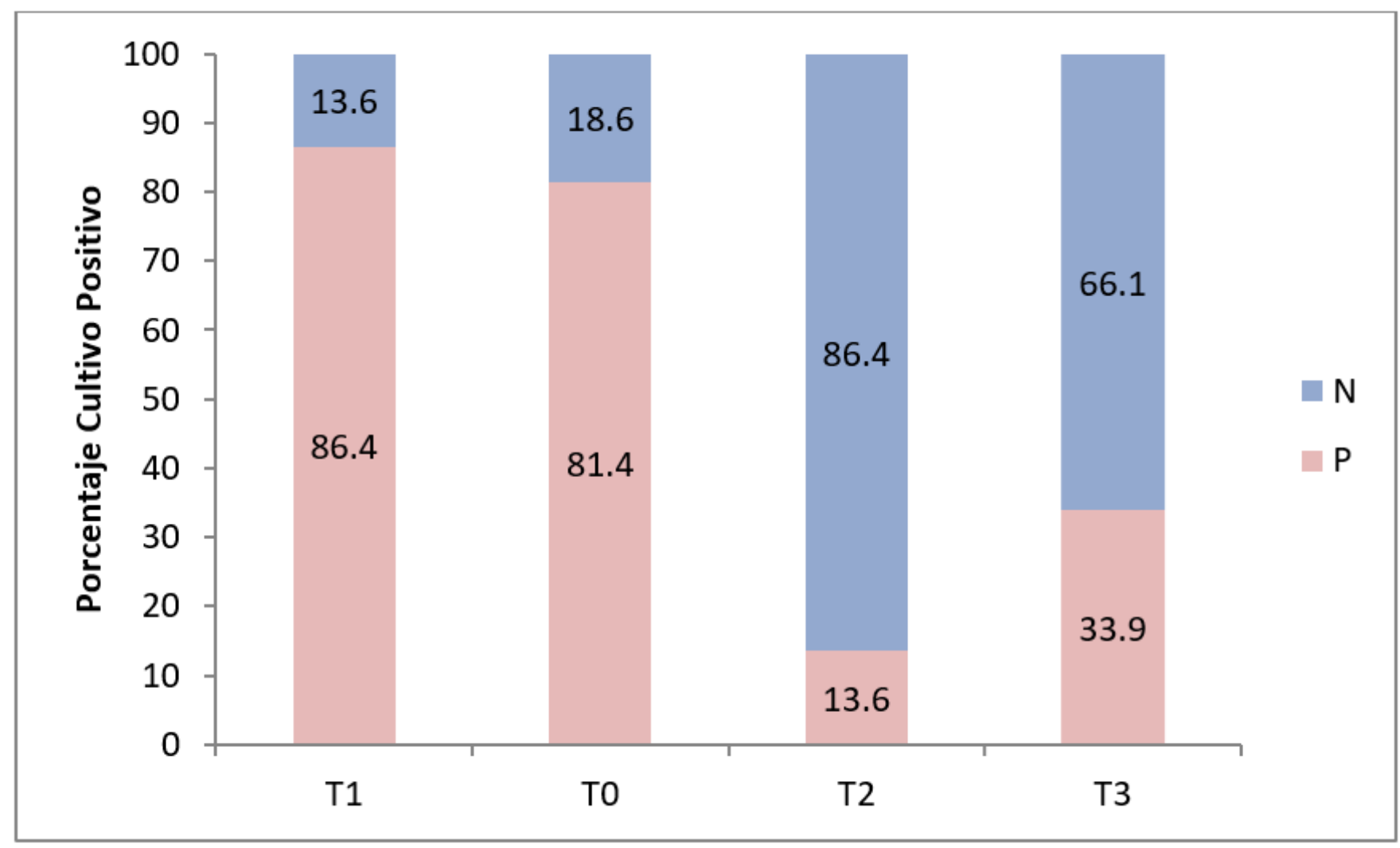

Figure 1

Comparison of the percentage of positive culture for coagulase negative staphylococci in the three times. T0: before the eye surgery to be operated. T1: from the fellow eye as control. T2: immediately after standard 5\% PVI disinfection. T3: at the end of the surgery. 